\title{
COMBINATION OF SOYBEAN MEAL AND Hibiscus tiliaceus LEAF IN THE GOAT DIET: EFFECT ON SOME PARAMETERS OF CARBOHYDRATE METABOLISM
}

\author{
A. K. Armayanti ${ }^{1}$, L. K. Nuswantara ${ }^{1}$ and J. Achmadi ${ }^{1,2}$ \\ ${ }^{1}$ Faculty of Animal and Agricultural Sciences, Diponegoro University, \\ Tembalang Campus, Semarang 50275 - Indonesia \\ ${ }^{2}$ Corresponding E-mail: jachmadi@gmail.com
}

Received June 12, 2015; Accepted August 21, 2015

\begin{abstract}
ABSTRAK
Penelitian ini bertujuan untuk mengkaji efek kombinasi dari daun waru dengan protein bungkil kedelai dalam pakan pada beberapa parameter metabolisme karbohidrat. Materi yang digunakan adalah 16 ekor kambing Peranakan Ettawah berumur 7 bulan dengan bobot badan $16 \mathrm{~kg}$. Perlakuan terdiri dari $\mathrm{T} 0=$ Pakan komplit (saponin dan waru $0,90 \%$, PK 8,69\%, TDN 62,11\%), T1 $=\mathrm{T} 0+3 \%$ protein bungkil kedelai, $\mathrm{T} 2=\mathrm{T} 0+6 \%$ protein bungkil kedelai, dan $\mathrm{T} 3=\mathrm{T} 0+9 \%$ protein bungkil kedelai. Penelitian ini dilakukan dengan menggunakan rancangan acak lengkap dengan 4 perlakuan dan 4 ulangan. Hasil penelitian menunjukkan bahwa perlakuan ransum tidak menunjukkan pengaruh nyata $(\mathrm{P}>0,05)$ terhadap konsumsi bahan kering, karbohidrat, energi, konsentrasi butirat dan valerat rumen. Konsumsi protein, kecernaan pakan, konsentrasi asetat dan propionat rumen, estimasi $\mathrm{CH}_{4}$, rasio non-glukogenik meningkat $(\mathrm{P}<0,05)$ akibat perlakuan. Suplementasi protein dalam daun waru yang terkandung dalam pakan disarankan harus diseimbangkan dengan tingkat energi.
\end{abstract}

Kata Kunci : defaunasi, suplementasi protein, pemanfaatan karbohidrat, kambing

\begin{abstract}
The purpose of this study was to clarify effect of the combination of waru leaf (Hibiscus tiliaceus) sapponin with soybean meal protein in the goat diet on some parameters of carbohydrate metabolism. The study used 16 Ettawah cross bred male goats with body weight average of $16 \mathrm{~kg}$ and aged at 7 months. The dietary treatments were: $\mathrm{T} 0=$ total mixed ration $(0.09 \%$ of Hibiscus tiliaceus leaf sapponin, $8.69 \%$ of $\mathrm{CP}, 62.11 \%$ of $\mathrm{TDN}), \mathrm{T} 1=\mathrm{T} 0+3 \%$ soybean meal protein, $\mathrm{T} 2=\mathrm{T} 0+6 \%$ soybean meal protein, and $\mathrm{T} 3=\mathrm{T} 0+9 \%$ soybean meal protein. The treatments were allotted in a completely randomized design, with 4 treatments and 4 replicates of each. The results showed that dietary treatments did not effect significantly $(\mathrm{P}>0.05)$ on intakes of dry matter, carbohydrate, energy, ruminal butirat and valerat concentrations. Crude protein intake, feed digestibility, ruminal acetate and propionate concentrations, ratio of non-glucogenic to glucogenic VFAs, and estimated methane production were increased $(\mathrm{P}<0.05)$ by dietary experiments. The protein supplementation in a Hibiscus tiliaceus leaf contained diet should be balanced with the energy level.

Keywords: Hibiscus tiliaceus, protein supplementation, carbohydrate utilization, goat
\end{abstract}

\section{INTRODUCTION}

A role of rumen protozoa on the utilization of feed carbohydrate has been studied to some extents in ruminants. The rumen microbes play an important role in feed digestion but defaunation generally has negative effect on ruminal fiber degradation, although removing protozoa from rumen reduces methanogenesis positively (Mosoni et al., 2011). In sheep fed on fiber rich 
diet, partial defaunation increases positive effect of rumen protozoa and decreases negative effect of protozoa (Han et al., 1999). Protozoa rumen reduces starch digestion in sheep (Mendoza et al., 1993). Defaunation combined with no nitrogen supplementation decreased ruminal fiber digestion (Ushida and Kojima, 1991). Ruminal volatile fatty acids concentration tended to be higher in defaunated than in faunated steers (Grummer et al., 1983).

The defaunation may affect on the growth of rumen bacteria negatively, because ruminal ammonia concentration was decreased (Kiran and Mutsvangwa, 2010) and ruminal volatile fatty acids concentration was increased (Han et al., 1999) in defaunated ruminants. These facts in turn may decrease capability in the ruminal fermentability for dietary fiber. Thus, a protein supplementation is postulated to ameliorate the negative effect of defaunation in ruminal digestion for dietary carbohydrate.

Soybean meal is used commonly as a protein source in ruminant. The sapponin of Hibiscus tiliaceus leaf was proved to be a potent defaunating agent (Istiqomah et al., 2011). The objective of this research was to study the combination effect of Hibiscus tiliaceus leaf sapponin and soybean meal protein on some parameters of carbohydrate metabolism in young goat.

\section{MATERIALS AND METHODS}

\section{Animal dan diet}

Sixteen male of Ettawah grade goats with body weight average of $16 \mathrm{~kg}$ and aged at 7 months were used in the experiment. Each goat was housed individually in a metabolic cage. Table 1 shows the ingredient and composition of experimental diets. The experimental diets were: $\mathrm{T} 0=$ total mixed ration $(0.90 \%$ sapponin of Hibiscus tiliaceus leaf, $8.69 \%$ of CP, $62.11 \%$ of $\mathrm{TDN}), \mathrm{T} 1=\mathrm{T} 0+3 \%$ of soybean meal protein, $\mathrm{T} 2$ $=\mathrm{T} 0+6 \%$ of soybean meal protein, and $\mathrm{T} 3=\mathrm{T} 0$ $+9 \%$ of soybean meal protein. The treatments were allotted in a completely randomized design. The drinking water was available at all time.

\section{Methods}

The research was conducted in two phases. The first phase was the preparation and formulation of total mixed rations as the experimental diets (Table 1). The second phase was a feeding trial for 10 weeks. After five weeks of adaptation to experimental diet and environment, each animal was performed on the test of feed digestibility for ten days. During the test of feed digestibility, amount of diet consumption was recorded and excreted feces was collected daily. The content of protein, carbohydrate and energy in feed and feces were analyzed according to the method of A.O.A.C (1990).

One week after the test of feed digestibility, blood sample was collected in each goat using a spoit via jugular vein. The blood sampling was conducted after one night of fasting (before feeding) and three hours after feeding. The blood sample was then analyzed for serum blood glucose concentration. Serum blood glucose concentration was assayed accoding to Coomer (1993). One week after blood sampling, rumen fluid sample was collected using the aspirated stomach tube in each goat. The rumen fluid sampling was performed after one night fasting (before feeding) and three hours after feeding. The sample of rumen fluid was then for determination of partial VFA concentration, namely acetate, propionate, butyrate, and valerate using the gas chromatography (Jouany, 1982). The ratio non-glucogenic to glucogenic VFAs was then calculated according to Ørskov and Ryle (1990). Based on data of VFAs, productions of methane were estimated using formula of Ørskov and Ryle (1990). Data parameters were tested using analysis of variance and followed by Duncan's multiple range test.

\section{RESULTS}

The level of protein supplementation did not affect significantly on daily intakes of dietary dry matter, carbohydrate, and energy (Table 2). Daily intakes of crude protein were increased $(\mathrm{P}<0.05)$ as increasing the level of protein supplementation. Dietary dry matter, crude protein, carbohydrate, and energy digestibilities were affected $(\mathrm{P}<0.05)$ by the level supplementation. The highest digestibilities of dietary dry matter, carbohydrate, and energy were achieved by the concentration of crude protein in diets at a level of $14 \%$ (Table 2).

Concentrations of ruminal acetate and propionate acids before and after feeding were increased $(\mathrm{P}<0.05)$ as result of the protein supplementation in diet (Table 2). Before and after feed consumption, treatment of protein supplementation did not effect significantly on concentrations of ruminal butyrate and valerate 
Table 1. Ingredients and Nutrient Compositions of the Experimental Diets

\begin{tabular}{lrrrr}
\hline \multirow{2}{*}{ Ingredients and composition } & \multicolumn{3}{c}{ Crude Protein Level of Experimental Diets, \% } \\
\cline { 2 - 5 } Ingredients, \% DM & 8.69 & 11.28 & 14.01 & 17.00 \\
Hibiscus tiliaceus leaf & 3.65 & 3.65 & 3.65 & 3.65 \\
Setaria sphacelata & 18.35 & 18.35 & 18.35 & 18.35 \\
Rice bran & 23.50 & 19.50 & 19.50 & 21.00 \\
Ground corn & 23.00 & 21.00 & 16.50 & 10.00 \\
Copral meal & 6.00 & 6.00 & 6.00 & 8.00 \\
Ground peanut shell & 16.50 & 16.50 & 16.00 & 14.00 \\
Molasses & 8.00 & 7.00 & 5.00 & 3.00 \\
Mineral vitamin mixtures & 1.00 & 1.00 & 1.00 & 1.00 \\
Soybean meal & 0.00 & 7.00 & 14.00 & 21.00 \\
${ }^{1}$ Nutrients composition, \% & & & & \\
Crude protein & 8.69 & 11.28 & 14.01 & 17.00 \\
Extract ether & 3.34 & 4.09 & 4.19 & 4.66 \\
Crude fiber & 22.63 & 25.82 & 27.84 & 29.22 \\
Nitrogen free extract & 52.62 & 47.78 & 43.85 & 36.03 \\
Ash & 12.22 & 11.02 & 10.11 & 13.08 \\
Sapponin & 0.90 & 0.90 & 0.90 & 0.90 \\
${ }^{2}$ Total digestible nutrients & 62.11 & 62.76 & 62.72 & 62.78 \\
\hline${ }^{2}$ Results of chemical analysis. & & & & \\
${ }^{2}$ Values were calculated based on Hartadi et & al. $(2005)$. & & & \\
& & & & \\
& & & & \\
& & & & \\
\end{tabular}

acids. The estimation of ruminal methane productions were increased $(\mathrm{P}<0.05)$ by the treatment of supplementation protein. The estimation of ruminal methane productions were higher $(\mathrm{P}<0.05)$ at after feeding than that of before feeding. The ratio of non-glucogenic to glucogenic VFAs during pre feeding period was not affected by treatments, but the values of ratio of non-glucogenic to glucogenic VFAs during post feeding period increased $(\mathrm{P}<0.01)$. The blood glucose concentrations were increased $(\mathrm{P}<0.05)$ by the protein supplementation.

\section{DISCUSSION}

\section{Nutrient Intake}

The sapponin of Hibiscus tiliaceus leaf at a dose of $0.9 \%(\mathrm{DM} / \mathrm{DM})$ in diet could be a potent defaunation (Istiqomah et al., 2011). In this study, experimental goats were designed to consume same sapponin amount of Hibiscus tiliaceus leaf with different protein amount of soybean meal. Amount of crude protein intakes were increased according to the portions of soybean meal in diets, while amount of dry matter, carbohydrate, and energy intakes were similar among treatment groups (Table 2). This fact indicated that goats consumed same sapponin level of Hibiscus tiliaceus leaf with different level of protein intake from soybean meal.

\section{Ruminal Fermentation of Feed Carbohydrate}

Before and after feeding ruminal propionate concentration was increased by the protein supplementation (Table 2), and this may agree with other studies. Kiran and Mutsvangwa (2010) 
Table 2. Experimental Results ${ }^{1)}$

\begin{tabular}{|c|c|c|c|c|}
\hline \multirow{2}{*}{ Parameters } & \multicolumn{4}{|c|}{ Crude Protein level of Experimental Diets, \% } \\
\hline & 8.69 & 11.28 & 14.01 & 17.00 \\
\hline \multicolumn{5}{|l|}{ Daily nutrient intake, $\mathrm{g} \cdot \mathrm{kgBW}^{-0.75}$} \\
\hline Dry matter & $42.54 \pm 10.41$ & $47.60 \pm 4.81$ & $39.42 \pm 5.21$ & $47.22 \pm 4.11$ \\
\hline Carbohydrate & $32.01 \pm 7.83$ & $35.04 \pm 3.54$ & $28.26 \pm 3.73$ & $30.82 \pm 2.68$ \\
\hline Crude protein & $3.70 \pm 1.02^{\mathrm{c}}$ & $5.37 \pm 0.54^{\mathrm{b}}$ & $6.70 \pm 0.89^{\mathrm{b}}$ & $8.03 \pm 0.70^{\mathrm{a}}$ \\
\hline Daily energy intake, $\mathrm{MJ} \cdot \mathrm{kgBW}^{-0.75}$ & $0.72 \pm 0.18$ & $0.78 \pm 0.08$ & $0.74 \pm 0.10$ & $0.88 \pm 0.08$ \\
\hline \multicolumn{5}{|l|}{ Nutrient digestibility, $\%$} \\
\hline Dry matter & $44.97 \pm 6.37^{\mathrm{b}}$ & $41.10 \pm 5.04^{\mathrm{b}}$ & $53.05 \pm 2.89^{\mathrm{a}}$ & $45.84 \pm 4.09^{\mathrm{ab}}$ \\
\hline Carbohydrate & $50.07 \pm 4.61^{\mathrm{a}}$ & $44.06 \pm 6.43^{\mathrm{ab}}$ & $50.62 \pm 3.39^{\mathrm{a}}$ & $39.88 \pm 4.93^{\mathrm{b}}$ \\
\hline Crude protein & $47.92 \pm 6.26^{\mathrm{b}}$ & $54.20 \pm 10.21^{b}$ & $74.72 \pm 2.45^{\mathrm{a}}$ & $68.35 \pm 4.67^{\mathrm{a}}$ \\
\hline Energy & $41.89 \pm 7.97^{\mathrm{bc}}$ & $34.46 \pm 5.40^{\mathrm{c}}$ & $56.46 \pm 8.48^{\mathrm{a}}$ & $50.70 \pm 11.48^{\mathrm{ab}}$ \\
\hline \multicolumn{5}{|l|}{ Ruminal VFAs concentration, $\mathrm{mM}$} \\
\hline \multicolumn{5}{|l|}{ Before feeding } \\
\hline Acetate & $34.34 \pm 1.43^{\mathrm{c}}$ & $40.16 \pm 2.11^{\mathrm{a}}$ & $38.97 \pm 3.42^{\mathrm{ab}}$ & $35.50 \pm 1.71^{\mathrm{bc}}$ \\
\hline Propionate & $14.57 \pm 0.97^{\mathrm{c}}$ & $20.52 \pm 1.76^{\mathrm{a}}$ & $17.41 \pm 1.76^{\mathrm{b}}$ & $19.23 \pm 1.93^{\mathrm{ab}}$ \\
\hline Butyrate & $7.89 \pm 1.93$ & $8.79 \pm 1.33$ & $8.18 \pm 2.41$ & $8.52 \pm 2.43$ \\
\hline Valerate & $0.65 \pm 0.20$ & $0.87 \pm 0.18$ & $0.79 \pm 0.10$ & $1.04 \pm 0.22$ \\
\hline \multicolumn{5}{|l|}{ After feeding } \\
\hline Acetate & $39.78 \pm 1.83^{b c}$ & $43.56 \pm 3.48^{\mathrm{ab}}$ & $47.01 \pm 0.90^{\mathrm{a}}$ & $39.29 \pm 3.39^{\mathrm{c}}$ \\
\hline Propionate & $17.21 \pm 0.71^{b}$ & $20.63 \pm 0.98^{\mathrm{a}}$ & $19.32 \pm 2.47^{\mathrm{ab}}$ & $20.29 \pm 1.80^{\mathrm{a}}$ \\
\hline Butyrate & $8.55 \pm 2.72$ & $6.71 \pm 4.02$ & $8.61 \pm 2.60$ & $9.06 \pm 6.53$ \\
\hline Valerate & $0.62 \pm 0.15$ & $0.77 \pm 0.08$ & $0.96 \pm 0.22$ & $1.03 \pm 0.32$ \\
\hline \multicolumn{5}{|l|}{$\begin{array}{l}\text { Ratio of non-gluconeogenic to } \\
\text { glucogenic VFAs }\end{array}$} \\
\hline Before feeding & $3.46 \pm 0.50$ & $3.60 \pm 0.25$ & $3.77 \pm 0.30$ & $3.57 \pm 0.53$ \\
\hline After feeding & $3.02 \pm 0.28^{b}$ & $2.91 \pm 0.28^{b}$ & $3.86 \pm 0.34^{\mathrm{a}}$ & $3.08 \pm 0.32^{\mathrm{b}}$ \\
\hline \multicolumn{5}{|l|}{ Estimated $\mathrm{CH}_{4}$ production, $\mathrm{mM}$} \\
\hline Before feeding & $13.92 \pm 0.56^{\mathrm{b}}$ & $15.60 \pm 1.00^{\mathrm{a}}$ & $15.63 \pm 1.51^{\mathrm{a}}$ & $13.48 \pm 0.52^{\mathrm{b}}$ \\
\hline After feeding & $15.91 \pm 0.97^{\mathrm{b}}$ & $17.03 \pm 1.82^{b}$ & $19.15 \pm 0.46^{\mathrm{a}}$ & $14.99 \pm 1.49^{\mathrm{b}}$ \\
\hline \multicolumn{5}{|l|}{ Serum blood glucose, $\mathrm{mg} \cdot \mathrm{dl}^{-1}$} \\
\hline Before feeding & $62.50 \pm 3.69^{\mathrm{b}}$ & $71.50 \pm 4.20^{\mathrm{a}}$ & $63.25 \pm 4.99^{\mathrm{b}}$ & $69.00 \pm 3.16^{\mathrm{ab}}$ \\
\hline After feeding & $64.25 \pm 2.98^{\mathrm{b}}$ & $73.00 \pm 6.78^{\mathrm{a}}$ & $65.5 \pm 3.96^{\mathrm{b}}$ & $71.00 \pm 2.16^{\mathrm{ab}}$ \\
\hline
\end{tabular}

${ }^{1}$ Values are means from 4 goats $( \pm \mathrm{SD})$. a,b,c,d $\mathrm{P}<0.05$ 
reported that the defaunation decreases ruminal acetate concentration and increases propionate concentration, and this effect is more pronounced when sheep are fed on a high protein diet. Defaunation tended to increase ruminal VFAs concentration in steers fed on diet high in dried whole whey (Grummer et al., 1983). Ruminal acetate and butyrate concentrations were decreased but propionate concentration was increased in defaunated sheep fed on high fiber diet (Han et al., 1999). The dietary starch degradation in rumen was increased in defaunated sheep (Mendoza et al., 1993).

There is a contrary between this experimental result and others (Kiran and Mutsvangwa, 2010; Grummer et al., 1983; Han et al., 1999; Mendoza et al., 1993), because before and after feeding ruminal acetate concentration was also increased by the protein supplementation (Table 2). As the part of this study, the rumen digestible organic matter was unaffected by protein supplementation (Akhsan et al., 2015). In other words, there was more portion of organic matter those may not be degraded into propionate acid which in turn increases proportion of ruminal acetate concentration. In addition, the experimental diets of this study were designed to be isoenergy. In other words, the levels of protein supplementations were not balanced with dietary energy (Table 1). Cantalapiedra-Hijar et al. (2009) reported that balancing high dietary energy and protein causes increased amount of the rumen digestible organic matter which in turn increases higher ruminal propionate concentration and lower acetate concentration compared with low quality diet in goats.

The dietary carbohydrate digestibility was decerased slightly by the protein supplementation (Table 2). The unchanged rumen digestible organic matter may also contribute to this result. Furthermore, the growth of rumen bacteria were not increased by the dietary protein supplementation combined with Hibiscus tiliaceus leaf, because the amount of estimated microbial nitrogen synthesis was unaffected by the treatments (Akhsan et al., 2015). On other hand, ruminal degradability of dietary neutral detergent fiber, acid detergent fiber and hemicellulose were increased by the defaunation in sheep (Han et al., 1999). Likewise, Mendoza et al., (1993) reported that amylolitic activity of rumen bacteria was higher in defaunated than that of faunated conditions. The defaunation with nitrogen supplementation increases cellulolylitic activity in vitro (Ushida and Kojima, 1991).

Mosoni et al. (2011) claimed that long term defaunation decreases ruminal methanogenesis, because protozoa are large producers of hydrogen, which is used as substrate by their methanogen symbionts to reduce carbon dioxide to methane. In contrary, the amount of estimated methane productions were increased by supplementation of protein in diets (Table 2). Values of methane production in this study were estimated using ruminal VFAs concentrations. The concentration of ruminal acetate caused the different in the methane production with that of Mosoni et al. (2011), in which methane production was measured directly.

\section{Utilization of Feed Carbohydrate}

The value of ratio of non-glucogenic to glucogenic VFAs may be used as a measure of carbohydrate feed utilization (Orskov, 2002). The defaunation and partial defaunation increase feed utilization which are showed by decreasing the values of ratio of non-glucogenic to glucogenic VFAs (Han et al., 1999). On the other hand, the protein supplementation slightly increased the ratio of non-glucogenic to glucogenic VFAs (Table 2). As mentioned above, the unchanged rumen digestible organic matter may increase the proportion of ruminal acetate concentration in VFAs. It is plausible because the ruminal acetate concentration takes a larger proportion in VFAs.

The glucose supply mainly from gluconeogenesis in ruminant, and ruminal propionate as a major source of the hepatic gluconeogenesis. Sheep may not rely mostly on hepatic gluconeogenesis, when they were fed on a high readily available carbohydrate based diet (Achmadi et al., 2007; Fujita et al., 2007). The treatment of soybean meal supplementation slightly increased before and after feeding blood glucose level (Table 2). It seems the supplementation of soybean meal and other ingredients in experimental diets may supply additional amount of readily available carbohydrate which in turn increases blood glucose of goats.

\section{CONCLUSION}

The Hibiscus tiliaceus leaf combined with soybean meal in a diet did not change the carbohydrate digestibility and ratio of nonglucogenic to glucogenic VFAs, but ruminal acetate and propionate concentrations and blood 
glucose level were increased by treatment of the Hibiscus tiliaceus leaf combined with soybean meal in young Ettawah cross bred goat. It is suggested that the protein supplementation in a Hibiscus tiliaceus leaf contained diet should be balanced with the energy level.

\section{ACKNOWLEDGMENT}

A sincere thanks was expressed to the Head and Staffs of "Pusat Pelatihan Pertanian Pedesaan Ramah Lingkungan-Kabupaten Barru Sulawesi Selatan", for facilitating authors to conduct this experimental animal. Data in this publication were partly presented in National Seminar of "Teknologi dan Agribisnis Peternakan" May 30, 2015 at University of Jenderal Soedirman, Purwokerto.

\section{REFERENCES}

A.O.A.C. 1990. Official Method of Analysis. $13^{\text {th }}$ Ed. Association of Official Analysis Chemist, Washington, DC.

Achmadi, J., E. Pangestu and F. Wahyono. 2007. Glucose tolerance and isulin response to intravenous glucose load in sheep on germinated sorghum grain. Asian-Aust. J. Anim. Sci. 20(10): 1575-1579

Akhsan, F., L. K. Nuswantara and J. Achmadi. 2015. Combination of Hibiscus tiliaceus leaf and soybean meal in the goat diet: Effect on some paramaters of protein metabolism. J. Indonesian Trop. Anim. Agric. 40(2):100106

Cantalapiedra-Hijar, G., D.R. Yanez-Ruiz, A.I. Martin-Garcia, and E. Molina-Alcaide. 2009. Effects of forage-concentrate ratio and forage type on apparent digestibility, ruminal fermentation, and microbial growth in goats. J. Anim. Sci. 87:662-631

Coomer, J. C., H. E. Amos, C. C. Williams and J.G. Wheeler. 1993. Response of earlylactation cows to fat supplementation in diets with different non structural carbohydrate concentration. J. Dairy. Sci. 76:3747-3754

Grummer, R.R., C.R. Staples, and C.L. Davies. 1983. Effect of defaunation on ruminal volatile fatty acids and $\mathrm{pH}$ of steers fed a diet high dried whole whey. J. Dairy Sci. 66: 1738-1741.
Fujita, T., M. Kajita, H. Sano and A. Shiga. 2007. Effects of dietary starch and sucrose on tissue responsiveness and sensitivity to in sulin in goats. Asian-Aust. J. Anim. Sci. 19: 1010-1018

Han, C.Y., D.X. Lu, M. Hu and Z.L. Tan. 1999. Influence of controlling protozoa on the degradation and utilization of dietary fibre in the rumen and nitrogenous flow entering the duodenum of sheep. Asian-Aust. J. Anim. Sci. 12(8): 1241-1245

Hartadi, H., S. Reksohadiprodjo, A.D. Tillman. 2005. Table Komposisi Pakan untuk Indonesia. Cetakan kelima. Gadjah Mada University Press. Yogyakarta.

Jouany, J. P. 1982. Volatile fatty acid and alcohol determination in digestive contents, silages juices, bacterial culture and aerobic fermentor contents. Sci. des Aliments. 2: 131-144

Kiran, D. and T. Mutsvangwa. 2010. Effects of partial defaunation on urea-nitrogen recycling, nitrogen metabolism, and microbial nitrogen supply in growing lambs fed low or high dietary crude protein concentrations. J. Anim. Sci. 88:1034-1047

Istiqomah, L., H. Herdian, A. Febrisantosa, and D. Putra. 2011. Waru leaf as saponin source on in vitro ruminal fermentation chararteristic. J. Indonesian Trop. Anim. Agric. 36: 43-49

Mendoza, G.D., R.A. Britton, and R.A. Stock. 1993. Influence of ruminal protozoa on site and extent of starch digestion and ruminal fermentation. J. Anim. Sci. 71: 1572-1578.

Mosoni, P., C. Martin, E. Forano, and D. P. Morgavi. 2011. Long-term defaunation increases the abundance of cellulolytic ruminococci and methanogens but does not affect the bacterial and methanogen diversity in the rumen of sheep. J. Anim. Sci. 89:783791.

Orskov, E.R. 2002. Trails and Trials in Livestock Research. Halcon Printing, Scotland. P. 137148.

Ørskov, E.R and M. Ryle. 1990. Energy Nutrition in Ruminants. Elsevier Science Publisher Ltd, London.

Ushida, K. and Y. Kojima. 1991. Effect of defaunation and refaunation of the rumen on cellulolitic activity in vitro with or without ammonia supplementation. Can. J. Anim. 71: 913-917. 